\title{
Using Magnetic Technique to Increase Efficiency of Organic Pollutants Biodegradation in Wastewater
}

\author{
Khalid Falih Hassan, Suadad Awad Kadhim, Noor Nihad Baqer and Elaaf Safa Al-deen Hassan \\ Ministry of Science and Technology, Directorate of Water and Environment, Baghdad 10001, Iraq
}

\begin{abstract}
The intensity of Magnetic field by 200, 300 and 400 gaos were selective to study their impacts on bacteria Bacillus, Pseudomonas and yeasts Candida dubliniensis, Candida glabrata, Issatchenkia orientalis and Rhodotorula mucilaginosa growth and to reduce organic pollutants in wastewater by COD, TOC, TN and TP in concentrations of 180, 75, 52 and $84 \mathrm{ppm}$ in $\mathrm{pH} 7.6$ and treatment periods of 2, 4, 6 and $18 \mathrm{~h}$ in batch system. Results showed that magnetic field 300 gaos had higher ability to increase bacterial and yeasts growth by $400-600 \%$ in $18 \mathrm{~h}$ and reduced COD, TOC, TN and TP by $88,85,90$ and $98.5 \%$ in same period treatment. While, the intensity of magnetic field 200 and 400 gaos have no effect on microorganisms growth and reducing organic pollutants. This study is first record for showing and explaining the positive effective of magnetic field on microorganisms growth.
\end{abstract}

Key words: Magnetic, yeast, bacteria, increase growth, biodegradation, wastewater.

\section{Introduction}

The waste water represents of the major sources of pollution to water bodies after being discharged into rivers without proper or partial treatment as it contains toxic organic substances that lead to a decline in natural water; and disruption the balance of the environment which causes the occurrence of water pollution. Wastewater treatment processes rely on assimilation of microorganisms and enzymatic effectiveness in breakage chains carbon of soluble organic pollutants; as sewage water contains many of the aliphatic, aromatic, phenolic compounds and toluene, which are toxic and carcinogenic compounds [1]. The bacteria are considered as the efficient microorganisms in biological treatments for waste water. It has the ability to secrete a wide range of analysis enzymes that break down organic substance and hydrocarbon and converting them into simple compounds; and adsorption a lot of heavy elements on the cell wall, in addition to its deployment in all aquatic body and rapid growth. Bacillus, Pseudomonas and some Micrococcus strains have

Corresponding author: Khalid Falih Hassan, B.Sc. Biology, research field: treatment technology of environment and water. highly efficiency for breakage of organic material soluble by enzymatic analysis [2].

Proved [3] in their study the ability of bacteria Chromatium and Bacillus consume sulfate significantly, in addition to nitrates and nitrites from polluted water and reduce their concentrations significantly. It has proven in considerable studies that bacteria have the ability to consume organic substances, hydrocarbon, phosphorus compounds and nitrogen because its system of enzymatic active that adopted on the basis of transferring energy which represented of Carbon from bacteria species to another [4].

Bacteria are divided into several classifications according to their ability of assimilation and breaking down such as Hydrolytic Bacteria, that secrete a group of enzymes working in the fragmentation of polysaccharides, fats and proteins convert into organic acids, amino acids and other simpler compounds. While, Fermentative Bacteria that work to convert these compounds into alcohol and fatty acid, then Acetogenic Bacteria convert it into Acetate and hydrogen. Whilst, Degradable Bacteria are working to break down these compounds and convert it into carbon dioxide and water [5]. 
Magnetic energy is an important role in the regulation of all forms life on the Earth's surface, and it has a very important role in regulating vital functions of all living organisms. Water significantly influenced by magnetic fields and composed of an atom of oxygen and two atoms of hydrogen, which gives it a polar character (bipolar charge). Water molecule is not exist as individual molecule in nature but it is formation as cluster, it is smallest unit building for water that its size depend on the number molecules which are entering to formation of water clusters and associated bonds with one another. The magnetic field contributes on the re-arrangement of the crystalline formation for water, which gives physical characteristic of water and it enables to penetrate the micro membranes faster through of orderly arrangement of molecules, as well as the magnetic field leads to increase the intra-spacing of molecules and reduce the surface tension and thereby increase the solubility of oxygen [6].

The magnetic property of the water utilized physically to develop the effective techniques for treatment waste water by using a magnetic field including CoMag technique which uses to acceleration the sedimentation and Coagulation processes in waste water treatment plants, as well as BioMass technology uses different intensity of magnetic field to increase the amount of Bioflox and thus increase the efficiency of wastewater treatment plants, these techniques have been adopted on influence in physical characteristics of the materials suspended and clumping rapid by using magnetic technique [6].

Global studies focused on using magnetic technique in the industrial, medical and agricultural areas and benefiting from the positive physical effects on water molecule. In a study [7] on the reduction of the concentration of organic contaminants from waste water olive oil industry by using magnetic nanoparticles they indicated the positive effect of these magnetic particles to change character wastewater physically and reduce the concentrations of contaminants efficiently.

As well as the magnetic field used in different intensities for killing bacteria and elimination, they showed [8-10] effectiveness of the magnetic field in killing of different species of bacteria like Streptococcus mutans, Escherichia coli.

Showed a study [11] the efficiency of the magnetic field in the reduction of pollutants from waste water for dyes industry and demonstrated that used of the magnetic field has affected significantly on declining of concentrations COD, NH4 and PO4 by rate $40-60 \%$ of the waste water.

Proved [12] in their study the deadly impact for the lower intensities of the magnetic field on bacteria Bacillus. Furthermore, it showed study [13] the efficient use of the magnetic field to reduce the concentrations of phosphate from sewage at rates large.

The current study is first of its kind, in interpretation of the positive influence of the magnetic field to increase the bacterial growth density and its exploitation in biodegradation of organic pollutants of wastewater, while all global studies focused on the use of magnetic technique to kill bacteria, or did not interested about the positive aspect of the magnetic field to increase the density the growth of these microorganisms and interpretation of this positive effect.

This study aims to experiment a range of intensities magnetic field to increase the density of microbiology growth and raise the efficiency of biodegradation of organic Pollutants in the wastewater.

\section{Material and Method}

\subsection{Collection and Preparing Sampling}

Sample of waste water collected from precipitation of secondary stage Russtamyia Treatment Plant to treatment of waste water by using plastic bottles $(5 \mathrm{~L}$ for each one) transferred to laboratory. Samples filtered by vaccum pump and using nitrocellulose filter paper with pore size $0.45 \mu \mathrm{M}$ for 
experimentation. Other samples collected from waste water by sterile glass bottles (100 $\mathrm{mL}$ for each one) for isolation and diagnosis bacteria and yeast.

\subsection{Cultivation Media}

Potato dextrose agar, yeast extract agar, Simon Citrate agar, Urea agar base, Nutrient agar, MacConkey agar, Eosinmethylene blue, Pseudomonas agar, Glucose azide agar.

\subsection{Chemical Tests}

Concentration of oxygen demand (COD), total organic carbon (TOC), total phosphorus (TP) and total nitrogen $(\mathrm{TN})$ were measured in wastewater sample before and after treatment, adopted on a standard method of analysis [14].

\subsection{Isolation, Cultivation and Diagnosis of Yeasts}

Yeasts isolated from waste water, PDA was prepared and added antibiotic chloramphenicol (prepared by dissolving $250 \mathrm{gm}$ from antibiotic to 250 $\mathrm{ml}$ of D.W). One milliliter of sample was put in sterile plates and then PDA was added in plates that contain the samples. Plates were incubated in $27^{\circ} \mathrm{C}$ for $48 \mathrm{~h}$. Swabs were taken from each colony by using sterile loop for cultivating in new plates with PDA by streaking method then incubation in $27{ }^{\circ} \mathrm{C}$ for $48 \mathrm{~h}$. After that, yeasts were diagnosed by biochemical tests according to the key classification [15] (Table 1).

\subsection{Isolation, Cultivation and Diagnosis of Bacteria}

\subsubsection{Total Count of Bacteria TPC}

One milliliter of waste water sample cultured by spreader method on nutrient agar by using dilution then plates were incubated for $24 \mathrm{~h}$ at $37^{\circ} \mathrm{C}$ and then the colonies were counted by colony counter [16].

\subsubsection{Isolation and Diagnosis of Bacteria}

One milliliter of sample waste water cultured by spreader method on nutrient agar, incubated plates for $24 \mathrm{~h}$ at $37^{\circ} \mathrm{C}$. A swab from each bacterial colony was transferred to diagnostic media (selective and differential) for differentiated bacterial species to obtain pure bacterial colonies. Biochemical tests were used to diagnose bacterial species. Bacillus was isolated and diagnosed of depending on method [17]. Pure isolation of the bacteria Pseudomonas aeruginosa was diagnosed by VITEK 2 compact system in bacteriology lab/research and water laboratories center/water and environment directorate/ministry of science and technology.

2.5.3 Test Precipitation of Salting Protein (salting out) [18]

The protein of milk was used for testing precipitation of salting protein to demonstrate the influence of a magnetic field on salt bridges, those which are linking of amino acids together and forming proteins. $100 \mathrm{gm}$ of powder protein was dissolved in $100 \mathrm{~mL}$ of distilled water and ammonium chloride was added to reach for saturation up to $60 \mathrm{~g} / 100 \mathrm{~mL}$ of distilled water.

\subsection{Magnets}

The use of magnet dipole (Fig. 1) that consists of two poles linked with a rod metal, through which a degree of magnetic intensities is controlled by moving the poles to get the intensities required, a set of magnetic intensity was tested to choose the best of positive effect on reducing the concentration of pollutants in waste water and increase of microbial growth rates.

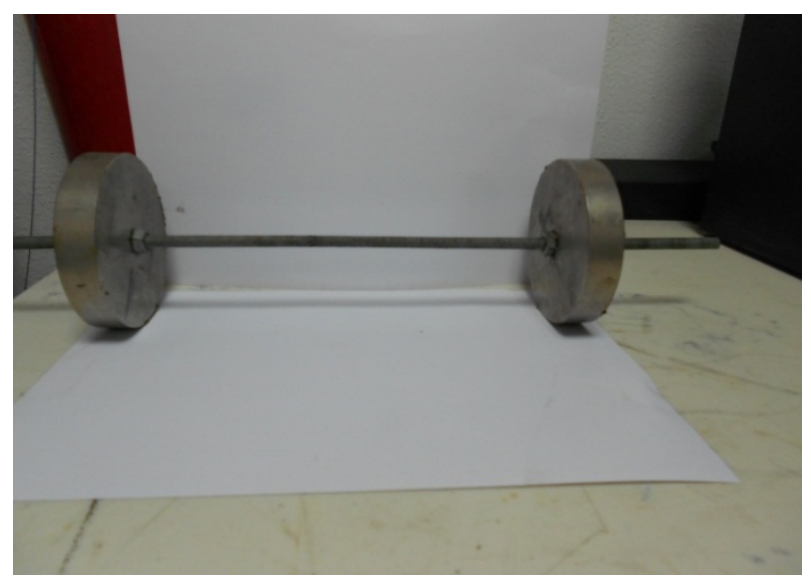

Fig. 1 Dipole magnets used in the experiments. 


\subsection{Experiments}

2.7.1 The Magnetization Effect on Reduction Pollutants

Unsterile sample of waste water was exposed to intensities of magnetic field 200, 300, 400 gaos for period 2, 4, 6, $18 \mathrm{~h}$ and measured of factors which included biochemical COD, TOC, TP and TN for samples before and after magnetization as indicator of pollution. Sample has been chosen from waste water without magnetization as a control group, which is measured in the same previous factors and the same period of intensities magnetic field.

\subsubsection{The Magnetization Effect on Yeasts}

Pure cultures of yeasts (Candida glabrata, Candida dubliniensis, Rhodotorula mucilaginosa, Issatchenkia orientalis) were used and grown in nutrient broth in volume $50 \mathrm{~mL}$ by sterile glass bottles and the number of yeasts was counted via using of Hemocytometer before and after exposure to intensities of magnetic field 200, 300, 400 gaos.

2.7.3 The Magnetization Effect on Total Count of Bacteria

Unsterile sample of waste water was exposed to intensities of magnetic field 200, 300, 400 gaos for period $18 \mathrm{~h}$. Sample has been chosen from waste water without magnetization as a control group. One milliliter of waste water sample cultured by spreading method on nutrient agar, plates incubated for $24 \mathrm{~h}$ at $37{ }^{\circ} \mathrm{C}$ and then the growing of colonies were counted by colony counter .

2.7.4 The Magnetization Effect on Bacteria

Pure cultures of bacteria used (Pseudomonas, Bacillus) were grown in nutrient broth in volume 50
$\mathrm{mL}$ by sterile glass bottles and the number of bacteria counted via using Hemocytometer before and after exposure to intensities of magnetic field 200, 300, 400 gaos for period 2, 4, 6, $18 \mathrm{~h}$. The number of bacteria was counted via using of Hemocytometer.

\subsection{Calculations}

The cells number of yeasts was enumerated by Hemocytometer (counting chamber) [16] according to equation:

(1) The number of cell $($ cell $/ \mathrm{ml})=$ the number of cell in 4 squares $\times 4 \times 10$

(2) The total number of bacteria TPC $=$ the number of bacterial cell $\times 1 /$ dilution factor

(3) Measurement of bacteria's size: measured size of bacterial cells by method $[19,20]$ through of the calibration ocular micrometer lenses of microscopic

(4) The percentage reduction of concentration pollutants after $18 \mathrm{~h}=$ Concentration of control after $18 \mathrm{~h}$-the magnetization after $18 \mathrm{~h} /$ Concentration of control after $18 \mathrm{~h} \times 100$

\section{Results and Discussion}

\subsection{Isolation and Diagnosis of Yeast}

Table 1 shows the results of biochemical tests for diagnosis yeasts Candida dubliniensis, Candia glabrata, Issatchenkiaorientalisand Rhodotorulamcilaginosa that isolated from waste water [21]. In their study proved the presence of Candida dubliniensisand Candida glabrata in waste water [22]. It has proven it is efficient in reducing concentration of phosphorous compound significantly. Shaym and Neelam [23] demonstrated in their study isolated yeasts Candida

Table 1 Biochemical tests for diagnosis of yeasts species in waste water.

\begin{tabular}{|c|c|c|c|c|c|c|c|c|c|c|c|c|c|}
\hline \multirow{2}{*}{ Yeast species } & \multicolumn{13}{|c|}{ Sugar Assimilation } \\
\hline & 1 & 2 & 3 & 4 & 5 & 6 & 7 & 8 & 9 & 10 & 11 & 12 & 13 \\
\hline Candida dubliniensis & - & + & - & + & - & - & + & + & + & - & - & + & + \\
\hline Candida glabrata & - & + & - & - & - & - & - & - & - & - & - & - & - \\
\hline Issatchenkiaorientalis & - & + & - & - & - & - & - & + & - & - & - & - & - \\
\hline Rhodotorulamucilaginosa & + & + & - & + & + & - & + & + & + & + & + & Weak & + \\
\hline
\end{tabular}


dubliniensisand Candia glabrata from waste water the efficiency of these species in reducing concentrations of phosphorus and organic compounds.

\subsection{The Magnetic Field Effect on the Reduction of Concentrations Pollutants from Wastewater}

Table 2 shows the reduction of pollutants from unsterile waste water in term of factors COD, TOC, TN and TP during the period of 2, 4, 6 and $18 \mathrm{~h}$ without treatment by magnetic field intensities, which considered as control. The concentrations factors of COD, TOC, TN and TP were 180, 75, 52 and $84 \mathrm{ppm}$ respectively. These values decreased, as COD value oscillated from $178-121 \mathrm{ppm}$. Whereas, TOC value was from $74-58 \mathrm{ppm}$, while, TN value was ranged from 51-38 ppm. As for, TP value fluctuated from 82-64 ppm during the period of treatment.

Table 3 appears the reduction of pollutants from unsterile waste water by indicating of factors COD,
TOC, TN and TP during the period of 2, 4, 6 and $18 \mathrm{~h}$ after exposure to intensity of magnetic field 200 gaos. The concentration of factors COD, TOC, TN and TP before magnetism was $180,75,52$ and $84 \mathrm{ppm}$ respectively. These values decreased, as COD value oscillated from 168-105 ppm. Whereas, TOC was value from 72-48 ppm, while, TN value was ranged from 49-28 ppm. As for, TP value fluctuated from 83-57 ppm during the period of magnetization.

Table 4 shows the reduction of pollutants from unsterile waste water by indicating of factors COD, TOC, TN and TP during the period of 2, 4, 6 and $18 \mathrm{~h}$ after treatment by intensity of magnetic field 300 gaos. The concentration of factors COD, TOC, TN and TP before magnetism was $180,75,52$ and $84 \mathrm{ppm}$ respectively. These values decreased, as COD value oscillated from 168-22 ppm. Whereas, TOC value was from 72-11 ppm, while, TN value was ranged from 49-0.5 ppm. As for, TP value fluctuated from 83-1.2 ppm during the period of magnetization.

Table 2 It shows the reduction of pollutants by indicating of factors COD, TOC, TN and TP for waste water sample (control group).

\begin{tabular}{llllll}
\hline \multirow{2}{*}{ Test } & The concentration & \multicolumn{4}{c}{ The concentration after treatment $(\mathrm{ppm})$} \\
\cline { 2 - 6 } & before treatment $(\mathrm{ppm})$ & $2 \mathrm{~h}$ & $4 \mathrm{~h}$ & $6 \mathrm{~h}$ & $18 \mathrm{~h}$ \\
\hline COD & 180 & 178 & 169 & 154 & 121 \\
TOC & 75 & 74 & 72 & 66 & 58 \\
TN & 52 & 51 & 48 & 43 & 38 \\
TP & 84 & 82 & 79 & 71 & 64 \\
\hline
\end{tabular}

Table 3 It shows the reduction of pollutants by indicating of factors COD, TOC, TN and TP for waste water sample treated magnetically by 200 gaos for period the magnetization of $2,4,6$ and $18 \mathrm{~h}$.

\begin{tabular}{llllll}
\hline \multirow{2}{*}{ Test } & The concentration & \multicolumn{4}{c}{ The concentration after treatment (ppm) } \\
\cline { 2 - 6 } & before treatment $(\mathrm{ppm})$ & $2 \mathrm{~h}$ & $4 \mathrm{~h}$ & $6 \mathrm{~h}$ & $18 \mathrm{~h}$ \\
\hline COD & 180 & 168 & 152 & 140 & 105 \\
TOC & 75 & 72 & 71 & 54 & 48 \\
TN & 52 & 49 & 44 & 35 & 28 \\
TP & 84 & 83 & 74 & 61 & 57 \\
\hline
\end{tabular}

Table 4 It shows the reduction of pollutants by indicating of factors COD, TOC, TN and TP for waste water sample treated magnetically by 300 gaos for period the magnetization of $2,4,6$ and $18 \mathrm{~h}$.

\begin{tabular}{llllll}
\hline \multirow{2}{*}{ Test } & The concentration & \multicolumn{4}{c}{ The concentration after treatment (ppm) } \\
\cline { 2 - 6 } & before treatment $(\mathrm{ppm})$ & $2 \mathrm{~h}$ & $4 \mathrm{~h}$ & $6 \mathrm{~h}$ & $18 \mathrm{~h}$ \\
\hline COD & 180 & 168 & 152 & 120 & 22 \\
TOC & 75 & 72 & 71 & 54 & 11 \\
TN & 52 & 49 & 44 & 35 & 0.5 \\
TP & 84 & 83 & 74 & 58 & 1.2 \\
\hline
\end{tabular}


Table 5 It shows the reduction of pollutants by indicating of factors COD, TOC, TN and TP for waste water sample treated magnetically by 400 gaos for period the magnetization of $2,4,6$ and $18 \mathrm{~h}$.

\begin{tabular}{llllll}
\hline \multirow{2}{*}{ Test } & $\begin{array}{l}\text { The concentration } \\
\text { before treatment }(\mathrm{ppm})\end{array}$ & \multicolumn{4}{l}{ The concentration after treatment $(\mathrm{ppm})$} \\
\cline { 3 - 6 } & $2 \mathrm{~h}$ & $4 \mathrm{~h}$ & $6 \mathrm{~h}$ & $18 \mathrm{~h}$ \\
\hline COD & 180 & 72 & 170 & 154 & 138 \\
TOC & 75 & 49 & 45 & 62 & 55 \\
TN & 52 & 83 & 71 & 41 & 35 \\
TP & 84 & 69 & 60 & 60 \\
\hline
\end{tabular}

Table 5 shows the reduction of pollutants from unsterile waste water by indicating of factors COD, TOC, TN and TP during the period of 2, 4, 6 and $18 \mathrm{~h}$ after treatment by intensity of magnetic field 400 gaos. The concentration of factors COD, TOC, TN and TP before magnetism was 180, 75, 52 and 84 ppm respectively. These values decreased, as COD value oscillated from 178-138 ppm. Whereas, TOC value was from 72-55 ppm, while, TN value was ranged from 49-35 ppm. As for, TP value fluctuated from 83-60 ppm during the period of magnetization.

The results of current study show high efficiency to magnetic field with intensity 300 gaos in the reduction of pollutants by indicating of factors COD, TOC, TN and TP from waste water, as the rate of decline was 88 , $85,90,98.5 \%$ respectively after $18 \mathrm{~h}$. Whilst, the rate of decline to the control group was 33, 23, 27, 24\% respectively. The result [24] in their study on Dairy Wastewater and Domestic Sewage, it has been proven the efficiency magnetic field on reduction of COD, N-NH4, P-PO4 at rate 55, 66, 70\% respectively. Glenn [25] proved the ability of magnetic field to reduce the concentration of pollutants in fresh water and sewage at high rates.

The magnetic field effects on the physical properties of water by reducing the surface tension to the watery body and hence the increase of the solubility of oxygen, which leads to increase aerobic oxidation processes. On the other hand, the magnetic field works to rearrange the molecules regularly, leading to increase in the spacing between them and the penetration of the necessary oxygen molecules for oxidative processes. It provides more space surface to microorganism for moving through the watery body for the occurrence biodegradation by enzymatic analysis $[6,26]$.

Arts [2] proved in their study the ability of bacteria Psuedomonas and Bacillus in consumption of sulphate significantly, in addition to nitrates and nitrites from polluted water and reduce their concentrations significantly.

Nwaogu [27] showed the ability of bacteria Bacillus in reduction of phosphate, nitrates and nitrites from polluted water and convert it to stored food granules in their cells, as bacteria rely in its analytical activities of organic materials, it based on the needs of the important elements in the growth and division process. Bacteria need essential elements (macroelements) such as, carbon, phosphorus, nitrogen and sulfur; as well as, need microelements like calcium, iron, potassium, sodium, magnesium and some metals (cobalt, manganese, nickel and zinc). Bacteria degrade long chains from the organic matter to get the carbon element, releasing oxygen and hydrogen for consumption. The nitrogen component is gotten through ammonium compounds, nitrates, nitrites and ammonia; and is gotten phosphorus from phosphate compounds in chemical formula H2PO4-, HPO4-2, PO4-3 [28, 29]. Yeasts are of the microorganism that is efficient in biodegradation of organic pollutants in sewage water. Abdullahi [30] in their study showed the efficiency of Candida and Rhodotorula in reducing concentrations of pollutants and the use of these yeast in biofiltration with efficiently for more than $40 \%$, as well as, Woertz et al. [31] demonstrated the effectiveness of black yeast Exophialalecanii-corni to eliminate of toluene from waste gas streams. The results of current study [32] 
proved that the positive influences magnetic are affected by positive and negative ions and the amount of organic material. The effect is physically through the arrangement of molecules in the watery body and reduces the surface tension, so increase the solubility of oxygen, which leads to increase oxidative aerobic for organic and inorganic pollutants. As well as, the results [33] proved in their study on the influence of magnetic field on waste water that the selection of the appropriate magnetic intensity had a significant positive impact in reducing the concentrations of pollutants, as well as proved that for each type of waste has the intensity of a magnetic effective affect depending on the concentration of salts, ions, organic matter, hydrocarbon and the nature of its molecular structure, and this has been proved by the current study. When using intensities magnetic 200 and 400 gaos on waste water there was no impact of effective these ratios and were reduced concentrations of pollutants approaching to the value of the control group.

\subsection{The Positive Impact of the Magnetic Field on the} Total Number of Bacteria

Table 6 shows the positive effect of field magnetic with intensity 200, 300, 400 gaos on increasing the total number of bacteria for a period of magnetization 2, 4, 6 and $18 \mathrm{~h}$, the total number before treatment was 224-228 colony/mL but using the intensity of magnetic field 300 gaos was 228-2,200 colony/mL respectively. The total number of bacteria approach to control group, when using intensity 200 gaos was 225-444 colony/mL. While the effect was negatively on the total number of bacteria when using intensity 400 gaos compared with control group.

\subsection{The Positive Effect of Magnetic Field on Bacteria Pseudomonas aeruginosa and Bacillus spp}

Tables 7 and 8 show the effect of field magnetic with intensity 300 gaos on the growth of bacteria Pseudomonas aeruginosa and Bacillus spp. for a period of magnetization 2, 4, 6 and $18 \mathrm{~h}$. The number of Pseudomonas aeruginosa was $450-452$ cell $/ \mathrm{mL}$ after period of magnetization increased, the number of bacteria $450-44 \times 10^{4}$ compared with control 450-850 cell $/ \mathrm{mL}$. The number of Bacillus spp. was 350-354 cell $/ \mathrm{mL}$ before magnetization, while the number was $360-44 \times 10^{4}$ cell $/ \mathrm{mL}$ after magnetization compared with control $350-750$ cell $/ \mathrm{mL}$ whereas the intensity of 200 gaos did not appear of effective on growth bacteria and approach from control but the intensity of 400 gaos appeared negatively effect on growth of bacteria.

Table 6 It shows the effect of intensities magnetic field by 200, 300, 400 on the total of bacteria after $2,4,6,18 \mathrm{~h}$ magnetization.

\begin{tabular}{llllll}
\hline \multirow{2}{*}{ Groups } & The total number of bacteria & \multicolumn{4}{l}{ The total number of bacteria after treatment (colony/mL) } \\
\cline { 3 - 6 } & before treatment (colony/mL) & $2 \mathrm{~h}$ & $4 \mathrm{~h}$ & $6 \mathrm{~h}$ & $18 \mathrm{~h}$ \\
\hline Control & 224 & 225 & 229 & 305 & 448 \\
Magnetization 200 gaos 225 & 224 & 227 & 300 & 444 \\
Magnetization 300 gaos 228 & 228 & 258 & 656 & 2,200 \\
Magnetization 400 gaos 225 & 225 & 226 & 223 & 190 \\
\hline
\end{tabular}

Table 7 It shows the effect of intensities magnetic field on growth of bacteria Pseudomonas aeruginosa after 2, 4, 6, 18 h magnetization.

\begin{tabular}{|c|c|c|c|c|c|}
\hline \multirow{2}{*}{ Bacteria } & \multirow{2}{*}{$\begin{array}{l}\text { The total number of bacteria } \\
\text { before magnetization (cell/mL) }\end{array}$} & \multicolumn{4}{|c|}{ The total number of bacteria after magnetization $($ cell $/ \mathrm{mL})$} \\
\hline & & $2 \mathrm{~h}$ & $4 \mathrm{~h}$ & $6 \mathrm{~h}$ & $18 \mathrm{~h}$ \\
\hline Control & 450 & 450 & 480 & 520 & 850 \\
\hline Magnetization 200 gaos & 455 & 460 & 480 & 510 & 840 \\
\hline Magnetization 300 gaos & 452 & 460 & 680 & $15 \times 10^{4}$ & $44 \times 10^{4}$ \\
\hline Magnetization 400 gaos & 450 & 450 & 430 & 410 & 210 \\
\hline
\end{tabular}


Table 8 It shows the effect of intensities magnetic field on growth of bacteria Bacillus spp. after 2, 4, 6, $18 \mathrm{~h}$ magnetization.

\begin{tabular}{llllll}
\hline \multirow{2}{*}{ Bacteria } & $\begin{array}{l}\text { The total number of } \\
\text { bacteria before magnetization } \\
\text { (colony/mL) }\end{array}$ & \multicolumn{4}{l}{ The total number of bacteria after magnetization (colony/mL) } \\
\cline { 3 - 6 } & 350 & 350 & $4 \mathrm{~h}$ & $6 \mathrm{~h}$ & $18 \mathrm{~h}$ \\
\hline Control & 350 & 450 & 420 & 480 & 750 \\
Magnetization 200 gaos & 352 & 360 & 540 & $25 \times 10^{2}$ & $45 \times 10^{4}$ \\
Magnetization 300 gaos & 354 & 350 & 350 & 290 & 150 \\
Magnetization 400 gaos & 352 & &
\end{tabular}

Table 9 It shows the effect of intensity magnetic field 300 gaos on growth of yeasts Candida galbrata Issatchenkiaorientalis, Rhodotorula mucilaginosa and Candida dublinisis after 2, 4, 6, $18 \mathrm{~h}$ magnetization.

\begin{tabular}{llllll}
\hline \multirow{2}{*}{ Yeast } & The number of cell before & \multicolumn{4}{l}{ The number of cell after magnetization $(\mathrm{cell} / \mathrm{mL}) \times 10^{4}$} \\
\cline { 2 - 6 } & magnetization $(\mathrm{cell} / \mathrm{mL}) \times 10^{4}$ & $2 \mathrm{~h}$ & $4 \mathrm{~h}$ & $6 \mathrm{~h}$ & $18 \mathrm{~h}$ \\
\hline Issatchenkia orientalis & 45 & 56 & 87 & 350 & 2,000 \\
Control & 43 & 50 & 65 & 70 & 120 \\
Rhodotorula & 50 & 65 & 90 & 320 & 2,100 \\
mucilaginosa & 48 & 55 & 68 & 78 & 130 \\
Control & 40 & 57 & 75 & 315 & 2,700 \\
Candida dubliniensis & 45 & 55 & 62 & 80 & 160 \\
Control & 45 & 65 & 95 & 360 & 2,800 \\
Candida glabrata & 48 & 60 & 75 & 90 & 165 \\
Control & 48 & &
\end{tabular}

3.5 The Positive Effect of Magnetic Field on Yeasts Candida glabrata, Issatchenkia orientalis, Rhodotorula mucilaginosa and Candida dubliniensis

Table 9 shows the effect of field magnetic with intensity 300 gaos on the growth of yeasts Issatchenkia orientalis, Rhodotorula mucilaginosa, Candida dubliniensis and Candida glabrata for a period of magnetization 2, 4, 6 and $18 \mathrm{~h}$. The number of yeasts was $40-50 \times 10^{4}$ cell $/ \mathrm{mL}$ before exposure to the intensity of the magnetic field. After magnetization the number of Issatchenkia orientalis increased to $56-200 \times 10^{4}$ cell $/ \mathrm{mL}$ and Rhodotorula mucilaginosa increased to $65-2100 \times 10^{4}$ cell $/ \mathrm{mL}$, whilst the number of Candida dubliniensis 57-2700 $\times$ $10^{4} \mathrm{cell} / \mathrm{mL}$. The increase was in the number of Candida glabrata $65-2800 \times 10^{4}$ cell $/ \mathrm{mL}$ compared with control group through period of magnetization.

It proved the results of the current study. The large positive effects showed the intensity of the magnetic field 300 on increasing the growth of microorganism in waste water, as well as, the pure culture of bacteria and yeast. The results of this study do not correspond to the local and international studies. It is the first recording of the efficiency of the magnetic field in the increased growth of microorganisms and the interpretation of this positive impact. Scientific research has focused on the use of magnetic intensity to kill microorganisms and prevent their growth as in the study [8-10, 12].

The magnetic effectiveness based on molecules of dipolar within cell wall of bacteria Pseudomonas aeruginosa, Bacillus spp. and yeast Issatchenkia orientalis, Rhodotorula mucilaginosa, Candida dubliniensis and Candida glabrata. The cell wall of the microorganisms (bacteria and yeast) is composed of polysaccharides and protein with some differences in thickness of the layers and the quality of the polysaccharide and amino acids of the protein constituent [34]. Gram positive bacteria possess two type of cellular wall as internal and external cell wall, these composed of peptidoglycan, polysaccharides and Teichoic Acids [35]. Whilst, Gram negative bacteria composed of lipopolysaccharides and lipoprotein. As well as, the yeast cell wall composed of polysaccharides, protein and chitin [36].

Kim and Giovanni [37] proved that the protein 
layers located within the cell wall are composed of amino acids group (Alanine, Glycine, Leucine, Valine, Treptophan, Isoleucine) that are bipolar because of their terminal groups within the molecular structure as positive amino group $\mathrm{NH}_{4}$ and a negative carboxyl COO-. Proved William et al. [38] the presence of lipopolysaccharides and peptidic polysaccharides, that are dipolar via the presence of nitrogen, phosphor and groups of carboxyl. The amino acids are linked with each other and with layer of polysaccharides within the cell wall via hydrogen bonds and salt bridges [39], that are linking amino acids together by electrostatic force (Fig. 2).

Salt bridges and electrostatic forces that linked of amino acids influenced by the intensity of magnetic field when using of intensity of magnetic field 300 gas, so the Salt bridges and electrostatic forces lead to dilation of bacterial cell or yeast therefore, the size pore in cell wall will expand; thereby, this will increase the exchange of materials between the organism and its surroundings. This leads to increase in cellular metabolism and raise in the growth. Whilst the using of intensity magnetic 200,400 goas that the salt bridges break, thus the cellular wall degrades and causes killing of bacteria, this was confirmed by test (salting out) as the precipitation of protein in control sample however, in the magnetization sample do not occur sedimentation, this indicate that the intensity of magnetic field affect the salt bridges bond between amino acids. As the study showed [40] the intensity of

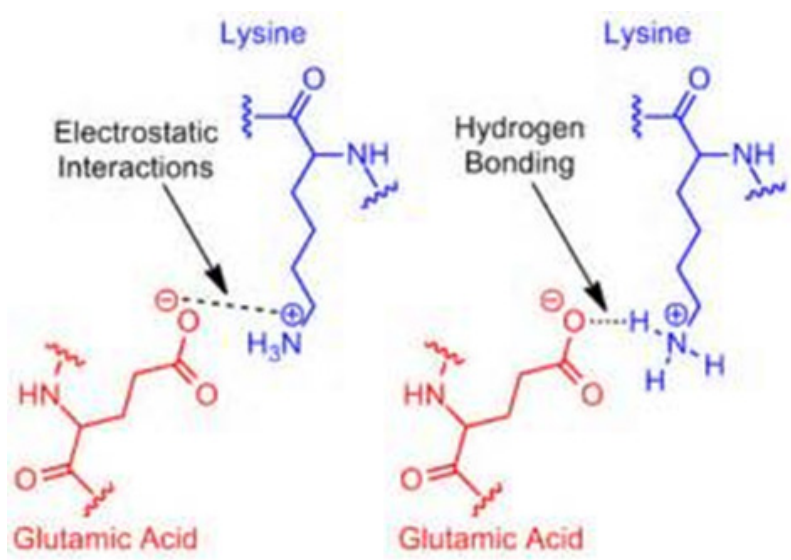

Fig. 2 Salt bridges linkedof amino acids. magnetic field is working to make changes within the crystalline clusters of water molecules for the presence of salt ions. In study [32], it showed the intensity of magnetic field have influence on the electrostatic force that exists between water molecules which gives positive physical characteristic to dissolve the salts and its precipitation. As study Feng [41] proved that changing of the crystalline structures of water by the magnetic field and the presence of salt ions. These studies have shown the efficiency of magnetic field with using its multiple in water to presence of concentrations of dissolved salt and proved the presence of concentrations salt are proportional with the magnetic effects.

Tests proved measure the dimensions of bacteria and yeast cells, the positive impact of the intensity of the magnetic field 300 gaos. The dimensions of the bacteria Pseudomonas to the control sample are 40-41 $\mu \mathrm{M}$, while in the magnetic sample are $51-57 \mu \mathrm{M}$, as well as increasing of bacteria size to $25-30 \%$ (Fig. 3). The dimensions of the bacteria Bacillus as in figure 4 for the control sample are $54 \mu \mathrm{M}$.

Whereas, the magnetic sample are $81 \mu \mathrm{M}$. Whilst, the dimensions of yeasts are 1.2-1.4 $\mu \mathrm{M}$ in control sample to 2.3-2.5 $\mu \mathrm{M}$ in magnetic sample, as well as, increased in size of cell 100\% (Fig. 5).

This is evidence of microorganisms elongation by the magnetic field and its impact on the salt bridges and electrostatic forces between amino acids within the cell wall.

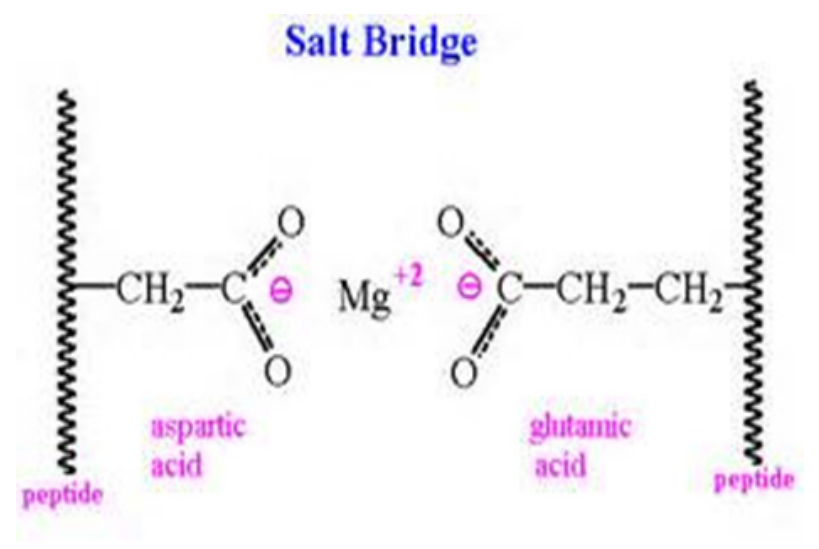



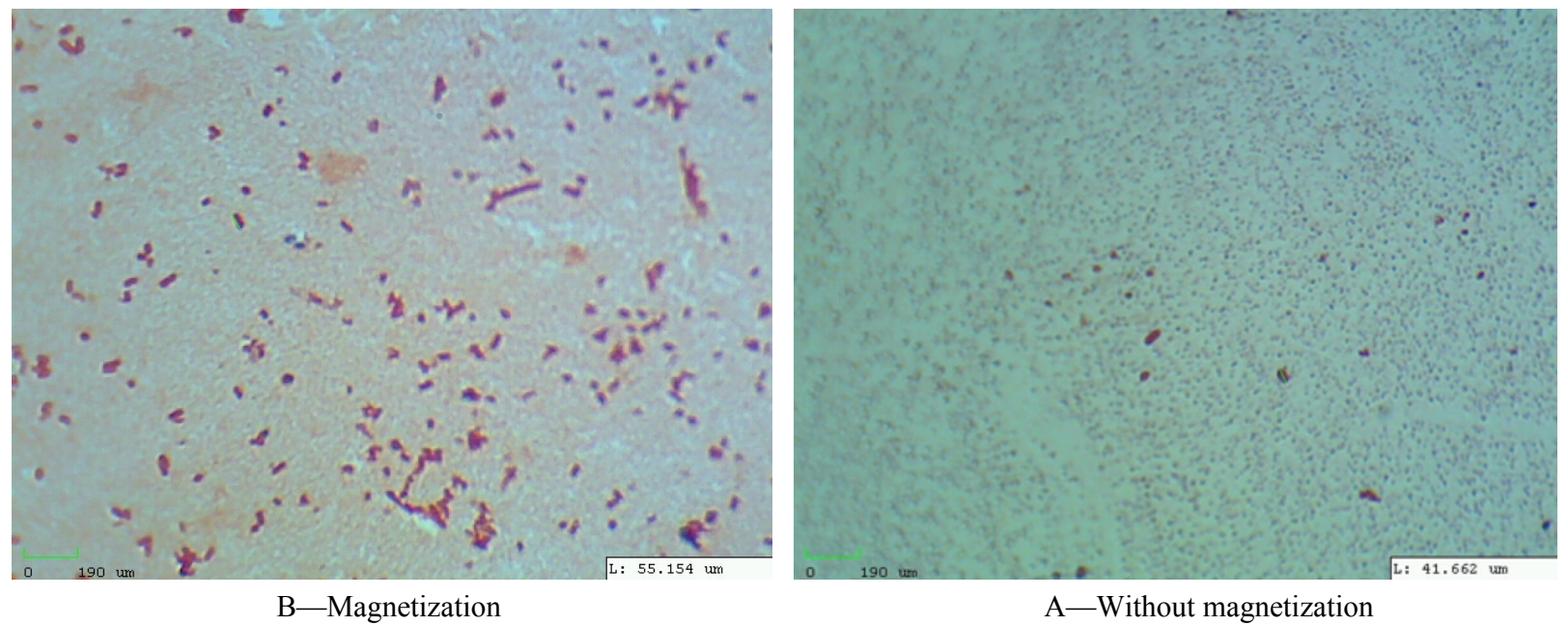

Fig. 3 The effect of magnetization on bacteria Pseudomonas aeruginosa.
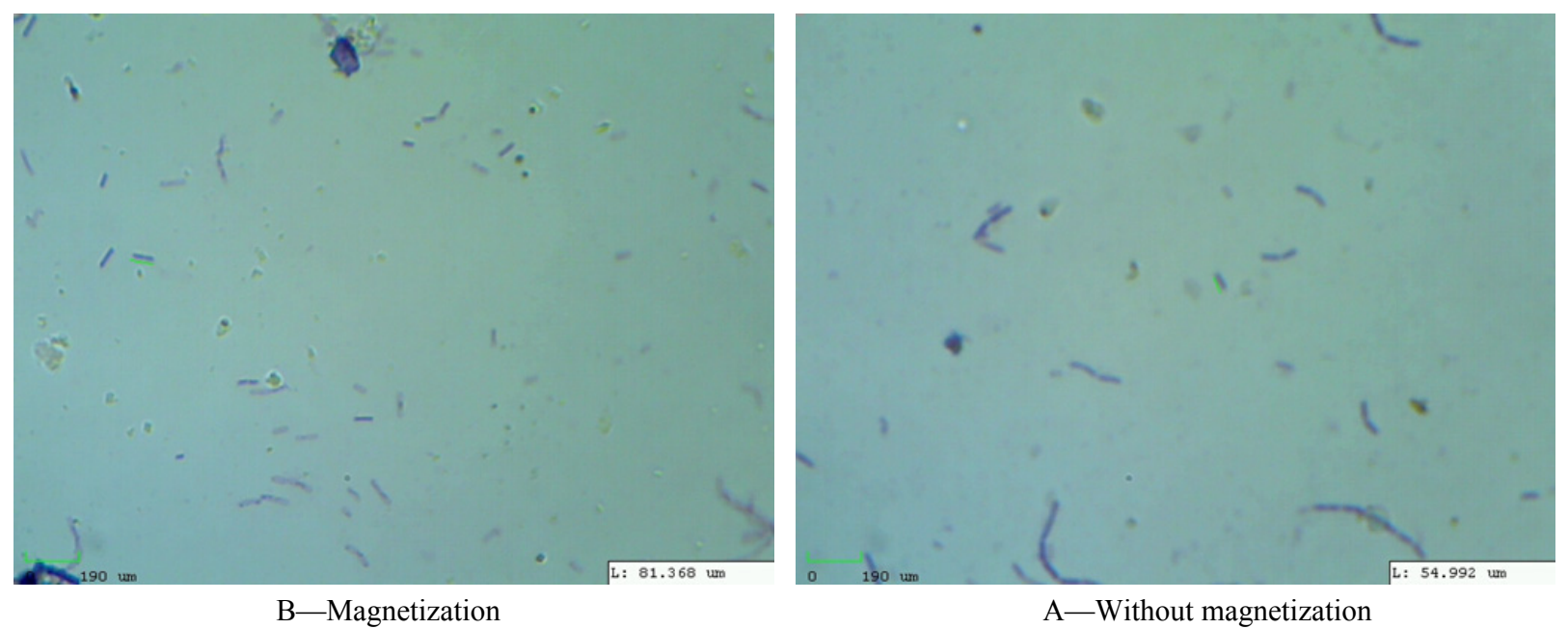

Fig. 4 The effect of magnetization on bacteria Bacillus.

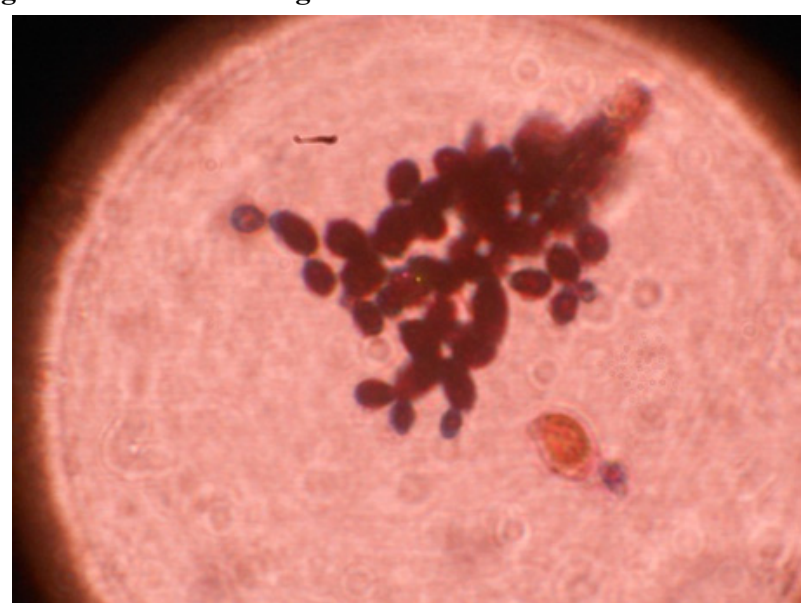

B-Magnetization

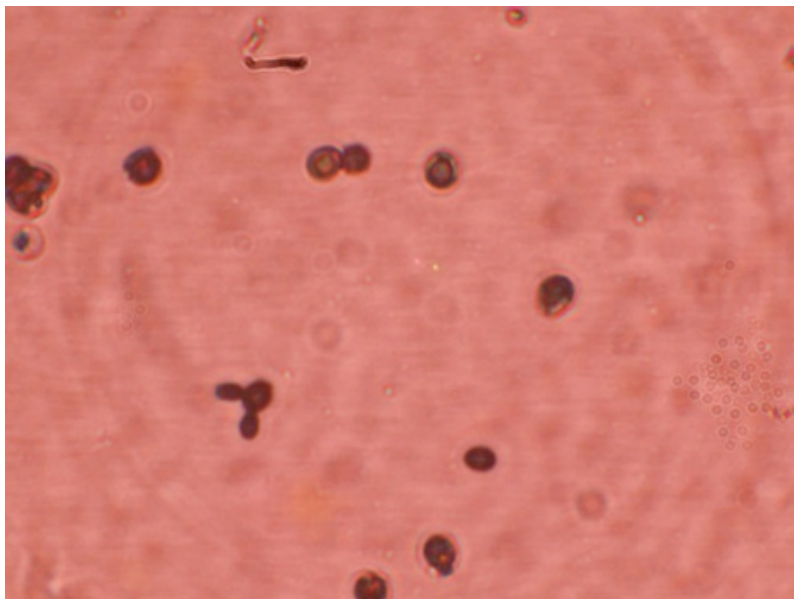

A-Without magnetization

Fig. 5 The effect of magnetization on yeast Rhodotorula mucilaginosa. 


\section{Conclusions}

(1) The intensity of magnetic field 300 gaos has large positive effects on increasing the growth of bacteria, yeasts and reducing the concentrations of pollutants in wastewater at high rates.

(2) The intensity of magnetic field 200 and 400 gaos showed efficient approach to control and did not have a positive impact on the growth of microorganisms or reducing the concentration of pollutants in wastewater.

\section{References}

[1] Luz, E. B., and Yoav, B. 2008. "Recent Advances in Removing Phosphorus from Wastewater and Its Future Use with Activated Sludge." Water Research 38: 4222-46.

[2] Arts, P., Robertson, L. A., and Kuenen, J. G. 2007. "Nitrification and Denitrification by bacteria in Aerobic Batch and Chemo Stat Cultures." FEMS Microbiol. Ecol. 18: 305-16.

[3] Mauro, T., Sandro, P., Dittmar, H., and Peduzzi, R. 2003. "Spatio-temporal Distribution of Phototrophic Sulfur Bacteria in the Chemocline of Meromictic Lake Cadagno (Switzerland)." Microbiology Ecology 43: 89-98.

[4] Wiesmann, U., and Dombrowski, E. 2007. "Fundamentals of Biological Wastewater Treatment." WILEY-VCH Verlag GmbH \& Co. KGaA, Weinheim, Federal Republic of Germany. Pp. 63-87.

[5] Michael, H. G. 2006. "Wastewater Bacteria." Williamsport, Pennsylvania USA. Pp. 78-95.

[6] U.S.A Environmental Protection Agency 2013. Emerging Technologies for Wastewater Treatment and In-Plant Wet Weather Management. Office of Wastewater Management U.S. Environmental Protection Agency Washington, D.C.

[7] Mohamed, A. A., Ali, F. M., Gaafar, E. A., and Magda, H. R. 1997. Effects of Magnetic Field on the Biophysical, Biochemical Properties and Biological Activity of Salmonella typhi. Master thesis submitted for Biophysics department, Faculty of science, Cairo University. Egypt.

[8] Kohno, M. F., Yama, Z. A., Kimura, I., and Wafa, M. C. 2000. "Effect of Static Magnetic Field on Bacteria streptococcus mutans and Escheriachia coli." J. Am. Pathophysiology 17: 143-8.

[9] Ceon, R., and Martin, J. T. 2005. "Low-level, Magnetic Field Induced Growth Modification of Bacillus subtilis." J. Bioelectromagnetics 8 (3): 275-82.

[10] Banejad, H., and Abdosalehi, E. 2009. "The Effect of
Magnetic Field on Phosphate Pollutants Compounds in Wastewater." Thirteenth International Water Technology Conference, IWTC 13 2009, Hurghada, Egypt.

[11] Akbar, E., Kensuke, S., Yoshiyuki, B., Masazumi, O., and Shigeo, A. 2006. "Magnetic Removal of Phosphate from Wastewater Using Schwertmannite." Materials Transactions 47: 1832-7.

[12] Morteza, H., Mohammad, J. M., Mohammad, B., and Saman, S. 2012. "Effect of Static Magnetic Field on Bacillus Growth." International Journal of Advanced Biotechnology and Research 3: 777-81.

[13] Yana, R., Marco, S., and Angelo, C. H. 2013. "Photocatalytic Treatment of Olive Mill Wastewater by Magnetic Core Titanium Dioxide Nanoparticles." Chemical Engineering Transactions 32: 2269-74.

[14] APHA 2012. Standard method for the examination of water and wastewater, 21th ed. American public Health Association, American water works Association and water pollution control federal, Washington, D.C..

[15] Kurtzman, C. P., and Fell, J. W. 1998. "The yeast: a Taxonomic Study 4th ed." Elsevier Science B.V.: 96-7.

[16] Prescott, L. M., Harly, J. P., and Klien, D. A. 2002. Microbiological 5th ed-London. MC Graw Hill Companies.

[17] Jennifer, M. P., Turnbull, P. C., and Gibson, J. R. 1983. "A Colour Atlas of Bacillus Species." Wolfe Medical Publication. London.

[18] David, Sh. 2009. Physical Biochemistry. Wiley Blackwell. Cambridge press. UK. p 285.

[19] Reynolds, C. S., and Jaworski, G. H. 1978. "Enumeration of Natural Microcystis populations.” British Phycological Journal 13: 1269-77.

[20] Lund, J. W., Kipling, G., and Le Cren, E. D. 1958. "The Inverted Microscope Method of Estimating Algae Numbers and the Statistical Basis of Estimation by Counting." Hydrobiologia 11: 143-70.

[21] Kurtzman, C. P., Fell, J. W., and Boekhout, T. 2011. "The Yeasts: a Taxonomic Study 5th ed." Elsevier Science B.V.: 230-4, 252-3, 268-9.

[22] Takashi, W., Noriatsu, O., Kazuhiro, I., Tsutomu, F., and Haruyuki, I. 2008. "Breeding of Wastewater Treatment Yeasts that Accumulate High Concentrations of Phosphorus." Appl. Microbiol. Biotechnol. 80: 331-8.

[23] Shaym, S., and Neelam, S. 2008. "Use of Polyphosphate Accumulating Organisms for Treatment of Phosphate Sludge." Proceeding of Taa 2007: The 12th World Lake Conference \India: 918-22.

[24] Krzemieniewski, M., Dębowski, M., Janczukowicz, W., and Pesta, J. 2004. "Effect of the Constant Magnetic Field on the Composition of Dairy Wastewater and Domestic Sewage." Polish Journal of Environmental Studies 13: 45-53. 
[25] Glenn, F. C., Mark, S. B., Kristina, P. R., and Julie, W. T. 2011. "Effects on Fresh Water Organism of Magnetic Fields Associated with Hydrokinetic Turbine." Annual Report. Oak Ridge National Laboratory Oak Ridge, Tennessee. USA.

[26] Štefušová1, K., Václavíková, M., Lovás, M., and Hredzák, S. 2012. "Use of Magnetic Filtration in Waste Water Treatment." Acta Montanistica Slovaca 17: 81-4.

[27] Nwaogu, L. A., Onyeze, G. O. C., and Nwabueze, R. N. 2008. "Degradation of Diesel Oil in a Polluted Soil using Bacillus." African Journal of Biotechnology 7 (12): 1939-43.

[28] Yoram, B., and VAN Rijn, J. 2000. "Atypical Polyphosphate Accumulation by the Denitrifying Bacterium Pseudomonas." Appl. and Environmental Microbiology 66 (3): 1209-12.

[29] Fry, J. C., Gadd, G. M., Herbert, R. A., Jones, C. W., and Watson-Craik, I. A. 2012. Microbial Control of Pollution. Society of General Microbiology, Cambridge University Press, London.

[30] Abdullahi, B. R., Lami, I., Udeme, J., Ijah, J., and Shu'aibu, B. M. 2011. "Assessment of the Efficiency of a Yeast Biofilter in the Treatment of Wastewater." African Journal of Biotechnology 10: 9347-51.

[31] Woertz, J. R., Kinney, K. A., McIntosh, N. D. P., and Szanisab, P. J. 2011. "Removal of Toluene in a Vapour Phase Bioreactor Containing a Strain of the Dimorphic Black Yeast Exophialalecarnii-cornii. Biotechnol." Bioeng 75: 550-8.

[32] Coey, J. M. D., and Cass, S. 2000. "Magnetic Water Treatment." Magnetism and Magnetic Materials 209: 74.
[33] Rao, M. S., and Omprakash, S. 2013. "Study of Electromagnetic Waves on Industrial Waste Water." Physics and Materials Chemistry 1 (3): 34-40.

[34] Lapidus, L., Eaton, W., and Hofrichter, J. 2000. "Measuring the Rate of Intromolecular Contact Formation in Polypeptides." Proc. Natl. Acad. Sci. 97: 7220-5.

[35] World Health Organization 2010. Recommendations for the evaluation of animal cell cultures as substrates for the manufacture of biological medicinal products and for the characterization of cell banks. Technical Report.

[36] Enrico, C., Dong-Hyun, R., Martin, S., Luciana, B. C., and Archana, V. 2001. "The Yeast Cell Wall and Septum as Paradigms of Cell Growth and Morphogenesis." J. Biol. Chem. 276: 19679-82.

[37] Kim, S., and Giovanni, Z. 2005. "Physics in Molecular Biology." Cambridge press.UK. Pp: 80-90.

[38] William, H., Christopher, S., Brent, L., Eric, V., and Bruce, M. 2010. "Organic Chemistry." Sixth edition. Cengage Learning International. China. Pp: 1101-10.

[39] Li, H., and Wingreen, N. S. 1997. "Nature of Driving Force Protein Folding: a Result from Analyzing the Statistical Potential." Phys. Rev. Lett. 79: 765.

[40] Iwasaka, M., and Ueno, S. 1998. "Structure of Water Molecules under 14 T Magnetic Field." Appl. Phys. 83 (11): 6459.

[41] Feug, P. X. 2008. "The Changes of Macroscopic Features and Microscopic Structures of Water under Influence of Magnetic Field." Elsevier, Physics 403: 357-61.

[42] Mara, D., and Horan, N. 2003. "Handbook of Water and Wastewater Microbiological Treatments." Academic Press, New York. Pp: 125-8. 